\title{
Behaviour Patterns at Places of Power in Northeastern Slovenia
}

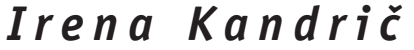 \\ Primary School Ormož, Slovenia \\ e-mail: irena.kandric@guest.arnes.si
}

\begin{abstract}
This article examines places of power as socio-culturally produced sites and associates them with religion, tourism and health. It addresses and classifies behaviour patterns formed by various visitors of what used to be predominantly pilgrimage places of power in Northeastern Slovenia (Razkrižje, Jeruzalem, Ptujska Gora). The examination of visits to the places of power combined with observation, qualitative interviews and analyses of entries into the book of impressions showed that visitors can be divided into five partially intertwining behaviour groups, based on the activities associated with tourism, religion (traditional Catholic and New Age), complementary and alternative medicine, and personal/individual behaviour patterns. The results confirm that old (traditionally Catholic) rituals are still performed in the Slovenian secular society and that New Age rituals are implemented.
\end{abstract}

Key words: anthropology, place, places of power, New Age, health, ritual.

\section{Introduction - places, places of power and visiting places of power}

The present study is placed into the perception of a "social or societal place" (Bourdieu, 1997; Lefebvre, 2013), that considers place a physical, geographical, measurable and abstract category, perception of which depends on society, history, intercultural and globalizing influences, performances, beliefs etc. Anthropologists have studied place as a complex cultural model; rarer individual studies study it more locally.

If phenomenology is included in the anthropological perspective of space, we must incorporate human practical placement into a certain environment; which means, on one hand, the presentation of place through "spatial representations" (landscapes, maps ...); on the other hand, it includes "spatial practices", which are spatial activities that contribute to the "social dialectics of place". In this study, we explore patterns of behaviour in places of power, and our anthropological purpose is not to find evidence to support the fact that visiting these spaces truly works, but it is an illumination of another aspect of people's lives and their functioning in relation to place, spirituality, health and tourism. Research studies, which can be associated with the topic of this paper, link the places with religion (especially pilgrimage sites), with health and tourism (Gordillo, 2002; Lockhart, 1999; Pernecky, 2006). Copyright (C) 2019 Institut za društvena istraživanja u Zagrebu - Institute for Social Research in Zagreb Sva prava pridržana - All rights reserved 
In Slovenia, the phenomenon of institutional and non-existential religiosity was ethnographically investigated by e.g. Ramšak (1996), Lipovec Čebron (2009), Ban (2014), Kravanja (2011), Šmitek (2017). The phenomenon of behavioural practices of modern non-institutionalized spirituality in correlation with space and health has not been frequently investigated by Slovenian anthropologists, so the decision was made to direct the research into this field, where New Age energy points, Catholic pilgrimage sites and tourist attractions are all connected in correlation to health.

Health and illness are socially and culturally conditioned, since every society recognizes, comprehends and defines the health of people, illness and healing in its own terms. Until the end of the First World War people with health problems turned mostly to medicine men, healers, religion, then the rise and development of allopathic medicine took place, and such forms of treatment started to decline. In the Slovene socialist and post - socialist society, illness was and is inextricably connected to medicine (Adam and Herzlich, 2002:25), but nevertheless, the studies of the last two decades (Toš and Malnar, 2002) indicate that there is an increased interest in non-medical, traditional forms of treatment among the people in Slovenia (Ule, 2003:263-265; Lipovec Čebron, 2008). The researched samples were analysed and studied by investigating which behaviour patterns are most common in the researched places of power in Northeastern Slovenia, whether they are related to health and what purpose do they serve. This was done since these particular behaviour patterns, in relation to the causes that prompt individuals to come to these places, point to the unexplored aspects of reasoning and the aspirations of modern people, trapped in a time of intertwining religious traditions, New Ageism and consumerism.

The designation of places of power was used due to the need for an expression that would combine traditional (Catholic) and New Age places with marked and unmarked energy points that attract visitors of various religious and spiritual traditions, tourists and individual researchers, who recognize such places as those with some particular "power". Various anthropological authors who have explored and researched "special" places have named them diversely; nevertheless, most of the research was related to traditional pilgrimage places and their researchers most frequently gave them the following names: "sacred spaces" (Morinis, 1992; Devereux, 2000; Huntsinger and Fernandez-Gimenez, 2000; Badone and Roseman, 2004), "holy places" (Greenfield, 1990; Badone and Roseman, 2004; Taylor, 2011), "pilgrimage places" (Turner, 1978; Delaney, 1990; Sallnow, 1991; Fartacek, 2003; Badone and Roseman, 2004), "places of wealth and poverty" (Gordillo, 2002). Individual research has also explored the appropriation of places (Olsen, 2008), however, in this research the controversy of these places ("contesting / contested places") has not proved to be a fundamental factor in the perception of these places (although the appropriation of places exists within certain groups). Nevertheless, observation and conversation have shown a fundamental emphasis on the attractiveness of these places. For visitors, these places are something "special", they are a place where, among other things, they "search for power" in order to live their lives to the fullest. The above mentioned terms are not entirely appropriate for our subject matter, since the basic concept of the phrase "pilgrimage places" is closely related primarily to 
Catholic pilgrimages and thus unsuitable for the identification of spiritual phenomena, also the term holy places (in articles the term is related to Catholic pilgrimage places) is difficult to connect with the New Agers, and the terms holy and sacred are even more difficult to associate with tourists coming to these places because of their specialty, attractiveness, special "power", but are not perceived as sacred by them.

In addition to this, the term "places of power" is more generic and is already used in literature (Ivakhiv, 2003; Nash, 2002; Gray, 2007), and is also acceptable for non-traditional spirituality (Castaneda, 1995; Stojanović, 2004) and studies of tourism (Pernecky, 2006). In his article, Ivakhiv (2003:94-96) confirmed that, as a whole, there is a frequent desire of New Agers to pay more attention to nature or the Earth, called "Gaia", in the modern world and to form a harmonious relationship with it. Simultaneously he studied the phenomenon of New Age pilgrimages to places of power. He included the explanation of the "spirit of place" within the Earth's energies, and the sacred geometry into New Agers' explanations of power of places and their figurative meaning. The idea of places of power, according to Ivahiv (2003:95), began to spread in folk consciousness in August 1987 with the Harmonic Convergence project, when New Age ceremonies (prayer, meditation and ceremony) occurred simultaneously in sacred cities around the world. According to the Encyclopaedia of Spirituality ${ }^{1}$ and the originator of such a name, Castaneda (1995:24-28), the term places of power denotes, in the context of New Age, larger or smaller geographical areas, where the "energy fields" are supposed to be important for humans. Such places were sometimes visited by former inhabitants and there they performed worship ceremonies, usually built shrines, monasteries (there are Catholic pilgrimage churches on all three researched places), and so on (Ban, 2014:73).

Visiting places of power, referred to as pilgrimage to holy places, goes back to the Catholic European tradition. Pilgrimage is a journey in faith, whether in the traditional sense or in the New Age meaning; it brings an individual into contact with the holy. The pilgrimage itself is not only a physical shift to a certain place for the visitor, it is also a path that contains trust, often hope, a faith in something, a search for contact with something holy and / or a search for inner peace, answers to important questions, truths, help, and comfort (Petrič, 2008:22). We treat visiting places of power as a ritual; the latter are, according to Cazeneuve (1986:14), an individual or group symbolic action that remains faithful to certain tasks. At the same time, according to Durkheim $(1976: 41,56)$, it contains rules that determine human behaviour in the presence of, for them, sacred objects, which are also valid for the behaviour in ceremonies at pilgrimage places and, if generalized, even at all places of power. And it is this ritual of coming to places of power, the behaviour, the differences and similarities between patterns of pilgrimage behaviour in the past and today, the differences, similarities and the entanglement between pilgrimage, New Age and tourist behaviour patterns of modern Slovenian visitors in places of power which is the subject of this contribution.

1 http://www.encyclopedia-of-religion.org/places of power.html 


\section{Methods}

The researched places of power (Razkrižje, Jeruzalem, Ptujska Gora) were placed into the research pattern due to the fact that these places have not yet been elaborately explored, additionally, because they have common points, many people visit them and think of them as their own.

Figure 1.

A map of NE Slovenia with marked researched places $^{2}$

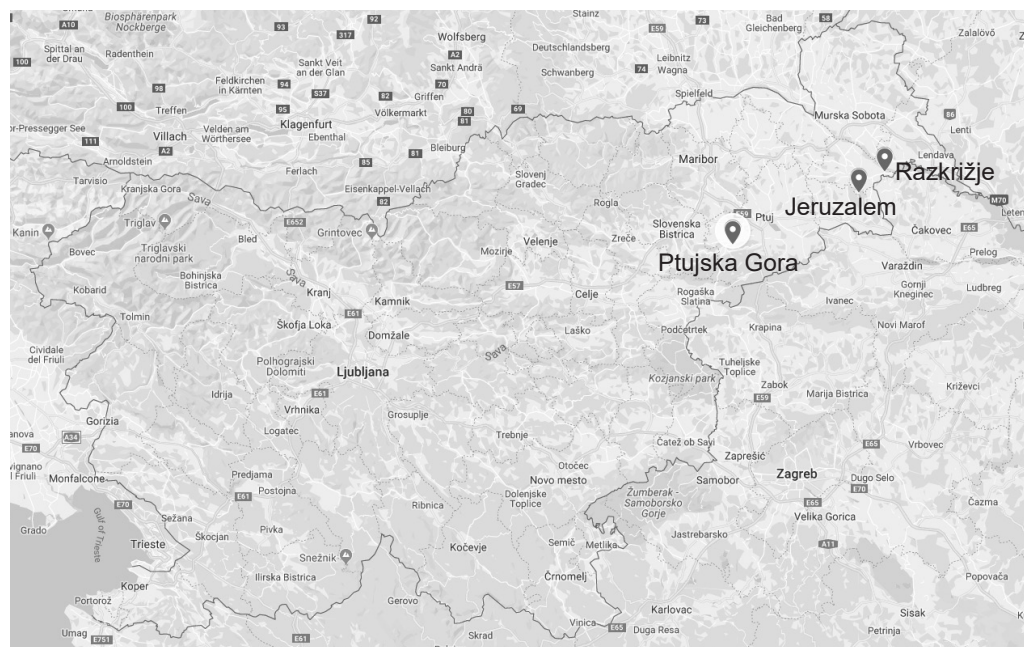

The selected places of power (Fig. 1) in Northeastern Slovenia (Razkrižje - a place in a small municipality on the border with Croatia, Jeruzalem - a village on the peak of a hill near Ormož in Prlekija, Ptujska Gora - a famous pilgrimage place with a basilica on the peak of a hill and near Ptuj) have been explored in a longitudinal study that lasted from 2006 to 2015 by the method of multi-sited ethnography (Marcus, 1995). Using this method, I could come and go to all three research places without living in any of them; and at the same time I lived in the midst of all three places, since I was at maximum 35 kilometres away from them. In this regard, the basis of the research was represented by the method of participant observation (that took place in front of churches and in them, in all three explored places, at designated energy points, at Ivan's spring in Razkrižje, in front of and in the taverns in Jeruzalem and Ptujska Gora). The fieldwork involved participation in numerous events: ceremonies (ethnological, religious, dramatic), masses, lectures, workshops (geomantic), individual and group visits (pilgrimage, tourist, New Age) to places of power, individual treatments. The method of observation was supplemented with the qualitative interview method. During the fieldwork, detailed, formal, informal and structured, partially structured and unstructured qualitative interviews with people of different ages were performed. Some interviews were done with spontane-

2 https://www.google.si/maps/place/Slovenija/Ž46.1634653.14.1234626,8z/data=!4m5!3m4!1s 0x476524e75e968361:0xe740451e25e2d465!8m2!3d46.151241!4d14.995463 
ous, brief (a few minutes long) informal talks, for example, at the source, others were held hours long (in-depth, formal and informal interviews); I spoke to 86 people in 72 interviews. Due to the desire to understand better and more easily the informers and the circumstances of the events, an analysis of the records from the book of impressions on Ptujska Gora (3 May 2009 - 8 August 2009) was added for an in-depth comprehension of causes and behaviours.

\section{Research participants}

New Age participants of the research believe that the power of the ritual is amplified in a place of power. According to Cazeneuve (1986:245-246), the ritual has a function of creating a sense of security, stability, belonging, continuity; it removes impurity, manages a higher power and connects a person with a sacred principle. Eade and Sallnow (1991) argue that despite of global understanding of the pilgrimage ritual (in our case, visiting the places of power), each pilgrimage is to be studied separately, and each category of pilgrims (visitors) has its own structure and its own understanding of pilgrims and the sense of pilgrimage. Their claim has reinforced my need to create a classification of behaviour patterns in the researched places of power, which lists numerous groups of visitors, each of whom has got its own patterns of behaviour. Traditional religious Catholic pilgrimage has been replaced in some places in the modern world; in others, it has intertwined with the New Agers and also tourist travels. Tourist visits to these places are also considered, since Leach and Aycock (1988) deny Durkheim's strict division into holy and profane, and reckon that tourist trips and travels have substituted pilgrimage in a secularized world, or tourist trips have become "secular pilgrimage". By doing so, they exempted the ritual from the sacred area and extended it to the world of the profane, which also gives the possibility of transferring the ritual of the sacred pilgrimage to the profane area, and simultaneously creates new forms of pilgrimages and ritual behaviour, also in various places of power. Concurrently, the need to classify the participants of the research, which were first divided into two large groups, depending on whether they come to the space of power as visitors or are current or former locals, has been confirmed.

The visitors of places of power were divided into five thematic groups based on their beliefs or actions, namely: (1) traditional Catholic pilgrims, (2) New Agers, (3) tourists, (4) professionals and (5) visitors of a spring and consumers of the water.

The first group is represented by (1) traditional Catholic pilgrims (they can come to Ptujska Gora every day, occasionally also to Jeruzalem, and once per year to Razkrižje).

The second group is represented by (2) New Agers who differed among themselves according to the criterion whether they are "less convinced" in their thoughts - practical practitioners of the New Age mentality (e.g. visitors of energy points) or "more convinced" New Agers, researchers and / or "professional" healers and / or "teachers" of a specific New Age technique that are interested in the operating of places 
of power, interpretation and perception of these places (geomants, bioenergetics, radiesthesists, Feng shui researchers, healers according to Voll ...). Research studies include members of the New Age movements that emerged in the 1980s among the New Agers, although their predecessors were already theosophists who developed their systems of ideas at the end of the 19th century. None of the above-mentioned New Age groups has binding texts, authority, or an organization; there are no strict rules in any of the groups listed; there is no need to believe in something; they gradually learn the rules of behaviour and thinking, and they are joined together by the desire to work on themselves, to reach personal growth, self-realization, achieve the "purging of negative patterns / beliefs / thoughts", gain better health, reaffirm individualization, come closer to nature, to the "higher ", to the "energy of the Earth and the cosmos" and also the belief that at the turn of the millennium we are in a period of great changes, when humanity is to be resurrected in terms of deep spirituality, coexistence and harmony. New Agers can "softly" pass between mentalities or can combine them; they have no myths or sacred books in common, a human being is primarily perceived as a spiritual being. They strive for personal and social transformation, spiritual growth, healing, learning about life, emphasizing optimism and other positive cultural concepts, for "searching" (authentic self); they often implement practices with "channelling" and demonstrate openness to some elements of the Asian tradition (Bahovec, 2009; Ban, 2008; Hanegraaf, 1998; Heelas, 1996; Potrata, 2001b; Črnič, 2012).

The third (3) group consists of tourists who only view these places. They are attracted by good advertising, beautiful photographs, pleasing descriptions that convince them in terms of interest, education and special appeal in the description that ads usually contain. The fourth (4) group consists of professionals (tourist workers, priests, scientists and experts from various fields (chemists, physicists, geologists ...) who try to find the explanations for researched places of power. The fifth (5) group is formed by visitors of the spring in Razkrižje who are also consumers of the water. Some accept the water as "healing" water, whereas others perceive it as nothing more than ordinary, fresh drinking water and do not think about it in terms of New Age as "special" water.

\section{Classification of behaviour patterns in researched places of power}

Sax (2009:52) highlights the connection between place and therapeutic practices, which are often closely related to the understanding of place and landscape, particularly because the area relays / expresses human history, memory and understanding. A ritual in the place of power is therefore a deliberately committed act, with a frequently predetermined purpose (meaning) and a pre-defined procedure (although many New Age rituals, unlike traditional ones, are loose); it carries a symbolic value in itself and takes place at a specific place at a given time. New Age rituals of visiting places of power are left to the current inspiration of a creative individual's composition of known elements (e.g. standing or sitting at stakes that mark energy points, crossing arms and legs, calming the mind and the body, drinking fresh spring water, washing eyes with spring water, etc.). 
At the places of power, patterns of behaviour are closely linked to the reasons why people come to these places. Observations of behaviour at places of power and conversations gave an insight into the patterns of behaviour that are most often repeated in the researched areas. Five thematic groups of behaviour were modelled according to the activities they associate with (1) tourist, (2) religious / spiritual (traditional Catholic and New Age), (3) healing, (4) consumer and (5) personal / individual patterns of behaviour. The greatest emphasis in this research was placed on religious and healing patterns of behaviour, since these patterns are the most common in the researched areas. At the same time, New Age models of behaviour, in this territory, form still unexplored ritual patterns that are often territorially or in substance intertwined with traditional Catholic and / or New Age patterns of behaviour.

Tourist behaviour patterns are very dispersed in the places of power, as the tourism industry is often seen as a market niche in the modern times, and therefore these geographic, natural and historical sites serve as a base for tourism. Among the tourist patterns of behaviour I have included sightseeing of places with a tourist guide, which is a fairly common form of behaviour, targeted by all tourist organizations, municipalities and church officials (a priest partakes the role of the guide), followed by individual sightseeing tours according to tourist guidelines, where individuals discover specialties of a place through the web, brochures, etc. Tourists who come to the explored places of power usually want to escape from the noise and crowds of people. Among tourist behaviour patterns, some are less frequent, for instance hiking (except for May 1st in Jeruzalem), cycling, panoramic motorcycle drives (on Jeruzalem and Ptujska Gora); visitors often come to Jeruzalem and Svetinje for the wine tasting and selling, wine and food catering, and there are consumer behaviour patterns associated with fairs at pilgrimage sites and tourist offices, where people usually shop for consumption and spend money. Even lodgings are part of the offer in certain places, which are mostly scattered in Jeruzalem with its surroundings. Additionally, at all three places there are occasional events as another form of acquiring visitors and behaviour thereof.

I divided religious behaviour patterns into two groups (traditional Catholic and New Age), based on fundamental religious or spiritual beliefs of an individual. Among traditional Catholic patterns of behaviour, I have included visiting masses that are conducted in all three explored places, but they are usually once or twice a week and on holidays in Jeruzalem, as there is only a visiting priest. Masses are held every day in Razkrižje, whereas on Ptujska Gora, as a pilgrimage place, there is more than one mass held every day, and at the end of the week there are specially organized masses dedicated to pilgrims. These also include prayers, which are at Jeruzalem sometimes accompanied by the lighting of candles and / or the ringing of the wishing bell. Blessings with water and incense are a part of church rituals, but priests do not bless believers in this way at every mass, usually these are reserved for festive masses or prayers of litanies. However, the faithful have the possibility, to cross themselves with holy water in each of these churches (as is customary in all churches), located at the entrance to the sanctuary; they can buy bottled holy water on Ptujska Gora; they can fill a bottle with it in Jeruzalem and if willing, they donate to the Church. Confession is a Christian sacrament, in which a believer asks God 
for the forgiveness of his sins through the priest, according to the priest's narrative on Ptujska Gora, there must be four priest confidants on the holidays to meet the number of confessors. Pilgrimage has in the past been a characteristic activity in all three researched places, but visiting Razkrižje and Jeruzalem slowed down in the post-war period, admittedly it never reached the dimensions that Ptujska Gora has had and still has. Requests, gratitude and vows are part of a ritual in a sacred place; the analysis of written entries on Ptujska Gora indicates that believers often come to a pilgrimage church to ask God, Jesus, Mary, angels or saints to help them with their problems, the troubles of someone close to them or to express their gratefulness or they swore an oath in a particular life situation that they would go on a pilgrimage or to some place of power in case their wish would be fulfilled, which some believers do quietly in prayer, some tell it to the confessor, and some also write this in the book of impressions (Jeruzalem and Ptujska Gora):

"Yes, we live in a very interesting time. You see, faith and these spiritual things are difficult to say publicly. [...] Of course, many people trust us, priests, but when we say that they could write it down, document it, then they say that they do not want that. That is interesting. Somehow people are still afraid of this. Sometimes for themselves, sometimes, for those whose health they have begged for." (Interviewee 60, a priest)

On Ptujska Gora, the visitors most frequently asked (256 requests) and / or thanked (50 acknowledgements) for health, since out of 1035 recorded examined impressions, 306 entries spoke about health, and of course they ranked first with 29.56\%. By the number in the pattern, the second place belongs to requests and acknowledgments for family (20.19\%), followed by requests and acknowledgments for protection (6.85\%) and for luck (6.57\%). Often, the topics of interaction are interlaced. When expressing a health-related desire, the improvement of health does not necessarily occur in the place of power itself, but faith and hope are also included in the possibility that the person will be referred to the right doctors, that the surgery will be successfully performed and that medical therapies will help, etc. (Kandrič, 2015:172)

The pilgrimages in the past and today, based on the researched sample in the Northeast of Slovenia, differ. The patterns of behaviour have been partially preserved, partially transformed. According to the old behaviour patterns, the pilgrimage day was a festive day, the pilgrims had wandered on their journey on an empty stomach, and the presence at mass was compulsory and desirable, which was usually followed by a snack, as my storytellers told me.

"My mother took a basket full of food with her. We were able to eat only after the mass, after the elderly had already received a holy communion." (Interviewee No. 43, retired).

After all this, a festive atmosphere and stands with souvenirs and lectar, decorated honey bread hearts with special messages written inside them, awaited pilgrims in front of the church and then they returned home. When observed the current 
pilgrims in Ptujska Gora during the research, I saw that they partook in pilgrimage mass, or just retreated into a silent prayer in the "empty" church, perhaps they only viewed the church, lit some candles in the church, rang the wishing bell. In the conversations, they said they consumed food mainly before coming to a place, during a visit to the place of power (for example, while waiting for mass) and after it. After visiting the place, today, they are also awaited by the stands with lectars and souvenirs in front of a sacred place on a festive day. (Souvenirs can be purchased every day in tourist centres in Jeruzalem and Ptujska Gora.). The festive atmosphere is only on a festive day. The visit ends with returning home. A comparison of pilgrim behaviour in the past and today shows a relaxation in the rules of behaviour at researched places in modern times, compared to the past, which is in accordance with the generally relaxed and modern-time adjusted patterns of Catholic religious behaviour.

The second group of religious behaviour patterns is formed by New Age behaviour patterns, which are often closely related to healing behaviour patterns. Some of the New Agers who came to the researched places, make a living through these activities, some have attended workshops, some have been individually educated, others have read about it, the fourth attempted to imitate someone they saw in this area. Among them were: radiesthesists, geomants, Feng shuiists, bioenergetics / bioenergetics, etc ${ }^{3}$. and consumers of energy points and spring water (The last two patterns of behaviour will be presented in the group of healing patterns.).

All members of the New Age in these areas are directed towards healing themselves, and geomancy also towards healing the place (They help themselves with cosmograms - imaginary messages translated into graphic form.). Geomants emphasize a new attitude towards themselves, nature, the connection with the Earth, its energies, the energies of the "higher", which they name differently. They have a respectful attitude towards water, and encourage individual personal growth. In geomancy, even channelling and conversation with elementary beings ${ }^{4}$ of nature occur. Although they are not of a physical nature, they can be perceived as a certain presence, such as the emotional quality of the atmosphere, according to the New Agers (Pogačnik, 2010:54, 125-131, 154). The highest developed elementary beings are thus committed to take care of connecting provincial units with the purpose designed for a specific place. The Ancient Romans knew, as claimed by Pogačnik (2010), of the spiritual guardians of places, homes called "geniuloci", geomants call these elemental beings the soul of the place / "animaloci", who are responsible for the etheric dimensions of the place.

According to the New Agers (Pogačnik, 2010:217-219), perception is not only on the physical level, it also includes an obligatory understanding of becoming in tune with

3 It should be noted, however, that the New Agers often put a certain practice in the forefront, while other practices, by their own choice, are often associated with basic practice.

${ }^{4}$ Elementary creatures of nature and the spirits of the environment are thought of as invisible and dematerialized beings (Pogačnik, 2010:54). 
a place, according to which, it is necessary to adjust oneself with the surrounding place, as a music player tunes her/his instrument before playing. This requires a loving, respectful approach to a place, a request for a key that an individual can receive in a form of a specific vision, intuition, etc., a request and a thank you for the contact with the place, as my speaker explained to me (Interviewee No. 2, geomant). My co-speaker clarified that the visitor must calm down, ground himself, connect with the place and perceive it as a form of consciousness before visiting it. Without the preparation and the key, man only comes to the "banal" level of the place. This was once known to the traditional Catholic pilgrims, who prepared to visit the pilgrimage place through prayers.

Among the healing behaviour patterns, in addition to all the above-mentioned religious patterns of behaviour, which are aimed at obtaining or maintaining health (traditional Catholic pilgrimage, prayers, requests and acknowledgements, lighting candles, ringing bells, payment of masses, New Ageism, geomantic treatment of oneself and the Earth), we also included the consumption of spring, healing water and other patterns of behaviour mentioned below, intended for the acquisition or preservation of health.

Water users from Ivan's spring in Razkrižje come to gather it as "living" water full of rich substances. This water is considered by the majority of visitors as something special (pilgrims in Razkrižje and local believers at the spring of St. Ivan (Fig. 1), New Agers as water full of "healing energies", and seekers of better health as natural spring water). For all these groups, this water is "sacred" or something "special". Petrič (2008:22) states that the ritual consumption of water in sacred Catholic places is also one of the forms of symbolic contact with the sacred powers of the place and an attempt to improve one's health. As an example, we can recount some of the world-famous Christian shrines that have water springs on their premises, to which they attach the potential of healing properties (e.g. the Virgin Mary Lourdes in France, Fatima in Portugal, Santiago de Compostela in Spain).

Figure 2

St. Ivan's spring of healing water

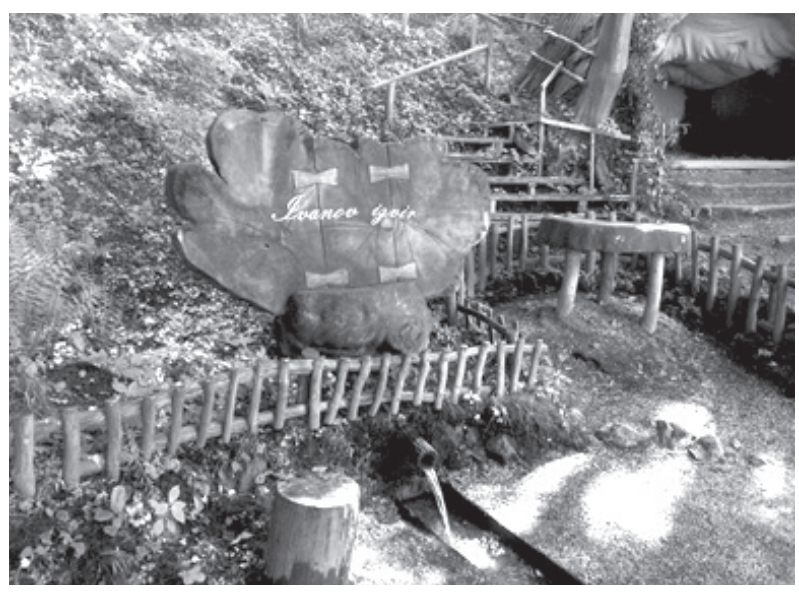


A historical overview of water symbolism demonstrates that most meanings of water are plotted around five general meanings: creation and birth, spiritual and emotional growth, cleansing, traveling and fulfilment (Stokowski, 2008:34-37). Even in the researched place, New Agers often come to get a "new life full of health", cleansing the ill and negative behaviour patterns within themselves, while often perceiving their arrivals to the spring as spiritual growth. They drink this water primarily to "heal" themselves.

Rarely, they only quench their thirst with it, and even less often they cook tea or coffee with it; most do not use it for cooking. Participation in the observation also provided information about interesting special uses of this water for homeopathic purposes, for homemade organic vinegar, etc.

Often the healing behaviour in Razkrižje and occasionally also in Jeruzalem is the New Age sitting at energetic points in places where, according to their beliefs, beneficial energies reside (Fig. 3). Visitors of energy points believe that it is possible to try to gain or maintain one's health through this type of behaviour. A New Age belief is that an individual must behave in the place of power according to certain rules, to feel it or to make an action occur.

"I came to the spring every day, I poured its water, I stood at the points or sat, but never with arms or legs crossed. I learned this from a local man who was involved in putting the markings on energy points." (Interviewee No. 31, farmer).

Figure 3.

Energy point in Razkrižje, where the healing pattern of sitting or standing is taking place

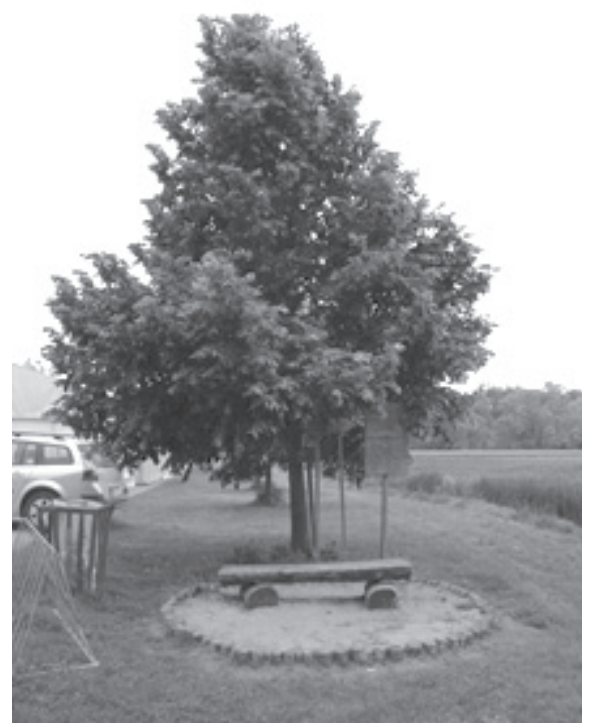

The third healing behaviour pattern includes walks in nature, which by themselves have beneficial effects on the individual, during them the person calms down, moves 
away from the fast pace of life, directs his/her attention to the plants along the path, the water, the beautiful view, the clapping of the rattle, etc. Relaxation may be associated with a walk, but this may possibly be due to coming to the place of power with a car, followed by relaxation, meditation, a "disconnection" from everything at the place of power. New Age diagnostics of a person's "health" status is possible in Razkrižje in agreement with a healer (radiesthesist, bioenergetic). Individual bioenergetic therapies are now possible in two explored places of power, in Razkrižje and in Jeruzalem, additionally there is also the possibility that the visitor of a place of power comes there with a bioenergethic therapist, reiki therapist, radiesthesist who helps him to feel these places or they perform therapy on them. Individual counselling treatment is a process in which individuals ask a radiesthesist, bioenergetics, geomant about how they should behave in a place of power, for example, to ensure that the energy points work, and then behave according to the instructions or as indicated by the readout.

Faith that a person can more easily come into contact with the holy in a sacred place than in a "normal" place, and that such contact with the holy can speed up treatments, is one of the main motives for visiting sacred places, both in traditional Catholic believers and in New Agers (Ban, 2008:87). According to this conviction "ordinary" practices in a sacred space often become "holy", a special quality that is beyond ordinary reality. The walk is no longer just a walk, but it is already a "treatment", as well as sitting in a forest or in certain places. And water is no longer just water, but it is special water (whether this is due to minerals, lack of chemicals or special energies). An individual that participates in an activity in a place of power sometimes exemplifies his own "ordinary" behaviour patterns, thus making them saintly, special and feels that he consumed the sacred place and its "special" features.

Consumer behaviour patterns are related to daily visits to the explored places associated with people who come for the water, because in some cases water from the water supply system needs to be periodically boiled (for example, Odranci), or simply because this water seems to be more delicious, therefore it is much more fresh and resembles the water from a former domestic well, a spring; but it does not matter to them that it is specifically Ivan's spring. This small group of water users emphasized that it is important for them that the water is biochemically checked, it is drinkable and does not need to be boiled, furthermore it is free of charge and / or that they prefer the taste.

Personal / individual behaviour patterns include the self-tangibility of place and its benefits, and the formation of their own behaviour patterns as an individual form of behaviour in which an individual may know something about these places, has read something about them, has consulted with someone, and then formed his/her own opinion and behaviour, or does not even think about these places, but he/she is simply enjoying being in the chosen place of power. Often, these visitors emanate various combinations and intertwine different selected behaviour patterns (tourist, traditional Catholic, New Age, consumer). Such visitors are usually trying to experience a place: 
"If you are trained, if you have finished this basic, preparatory or any other course, I am joking a little, I am not talking about courses, I am talking about the process of internal awareness, if you have matured to some extent, then you can also, very quickly, even in a minute come in tune with a place, but this is not possible if you do not nurture it, if you do not have the self-discipline to do it on a regular basis." (Interviewee No. 67, a New Ager employed in tourism).

\subsection{Linking behaviour patterns while one of the activities simultaneously dominates}

The integration of diverse activities is also known to providers who offer various combinations of activities to visitors in these areas. The first combination is linked to Jeruzalem and includes a tourist offer (excursion, catering), pilgrimage (pilgrimage church) and a New Age activity (placed energy points, geomantic camps ...). In Razkrižje, New Age (energy points, "healing" Ivan's spring) is in the forefront, followed by tourism (the walking path along the Razkriški kot, archaeological settlement ...), pilgrimage (church and the spring of St. Ivan) and consumer behaviour patterns (drinking "spring" water, which is not processed by technology and human intervention). Ptujska Gora connects pilgrimage activities (pilgrimage basilica), tourist activities (historical-geographical specialty of the hill and church), and a hidden, in a smaller proportion, remarkable New Age activity. The coexistence of different activities indicates that there is no absolute dominance of a particular activity; simultaneously tourism activities are often associated with a desire for a more comprehensive offer that would attract visitors. Tourist workers and local leaders often sought the advantages and distinctiveness of their place, and thus tried to highlight their potentials to attract tourists, thereby promoting their place and attracting visitors with their forte, as, for them, tourism is a "consumer good".

Turner (1978:207) defined pilgrimage as a symbolic, ritual activity with various activities that make it recognizable. The basic characteristic required for a pilgrimage (as a rite of passage) is the journey, and this separates it from other rituals, since the general spiritual values are strengthened by visits to pilgrimage places. The presence in such a place and in such a ceremony gives hope to individuals that they go through the direct experience of the holy and invisible (Turner, 1978:214). After a pilgrimage, a visitor of a place of power (sacred space) is reborn and as such returns to the existing social structure.

The research has revealed that various activities occur in different researched places in various stages of pilgrims visiting a place of power, and are considered as the ritual of transition. Places of power have a special "power" for everybody, despite different categories of visitors who, in various ways, participate in the sanctity of the place. Believers go on a religious pilgrimage; tourists do not only view sacred places and symbols, but they are also on a "pilgrimage", and the New Agers "tune in" through their rituals, through their own understanding of the place. Those who gather the water do not generally have "purely ordinary" water, although there is 
also a small portion of those who come there because of domestic non-drinkable water. Among the latter, there are also tourist workers who offer tourists everything they could "sell". In short, a place of power is a world for different groups of people that inhabit it in different ways. Definitely, there is a tendency that a sacred space is defined as "sacred", no matter what has occurred in the said place. Conversations with narrators and observation suggest that the diversity of space depends on the dominant activity (tourist, traditional pilgrimage, New Age) and the diversity of the individual (socio-cultural influence, his personality).

Behaviour patterns are intertwined in the fields of research; the consumer sample associated with pouring drinking spring water is only available in one area, as others do not offer this option. The remaining three patterns (tourist, religious, and healing) are represented in all three areas; one of the patterns stands out in each place, the rest are slightly in the background. In Razkrižje, they try to attract tourists by promoting the Razkriški kot, and they invested a lot in advertising new beneficial energy points and "healing water" from Ivan's spring, and thus indirectly put the New Age behaviour patterns in the forefront, which are now prevailing in the area. From the New Agers' point of view, Razkrižje has successfully been "conquered", and the New Age activity is being awakened in Jeruzalem with activities performed on occasional events (rare geomantic workshops and radiesthetic measurements, placement of stakes at energetic points), while Ptujska Gora remains only a little New Age. Tourist activity and associated behaviour patterns are at the forefront in Jeruzalem, although some agencies link it to pilgrimage, and an additional possibility of promoting the place has been identified by individuals and interest groups in recent decades in the promotion of the village. Traditional religious behaviour patterns are at the forefront on Ptujska Gora, where they often associate with tourists visiting the place; due to their dominance, the New Age behaviour remains almost imperceptible in this area and also has no special developmental possibilities. Observations and conversations have shown that personal / individual behaviour patterns are represented in all three places of behaviour, but they are somewhat obscured on the traditional Catholic Ptujska Gora.

\subsection{Health and patterns of behaviour}

Among the patterns of behaviour, the tourist, religious and healing patterns of behaviour stand out in frequency; at the same time, it is interesting that within these groups of patterns, the individual's concern for the preservation and / or acquisition of health or the prevention of illness, is the one most frequently expressed, which is covered in religious, healing and individual patterns of behaviour (e.g. pilgrimage to sanctuaries, drinking "healing" spring water, walks and calming one's mind and body). Studies of recent periods (Ule, 2003:263-265) also indicate that there is an increased interest among non-medical, traditional and complementary forms of treatment among people in Slovenia; this is also reflected in this research. Responsibility for health is no longer collective as it was in socialism, but rather individual, which corresponds with the thought of modern capitalist society (Potrata, 2001a:177). 
Besides taking care of physical health, mental health care has also increased in the places, which is especially noticeable in religious behaviour patterns (in both, traditional pilgrims and New Agers) and individual patterns of behaviour. In contrast to Christian believers, the New Agers do not try to get well through prayer and worship, but try to absorb the magical powers of the place, mingle with them (Ban, 2014:89) and with their help heal themselves. With such activities, a modern Slovenian shows concern and willingness for personal growth in different areas and levels, as can be seen from the findings of Huntsinger and Fernandez-Gimenezova (2000:543) and Potrata (2001a:177). Visitors of places of power that feel independent and work within small groups or individually strive to "work on themselves" and their personal spiritual growth. Simultaneously, the increased disciplinary role of medicine in modern society (Malnar, 2002:3-26), beside the treatment and healing of an individual's biological body, influences the mentality and the way of life of a modern person, and requires various techniques of self-discipline and care for one's own body, which is in accordance with the New Age mentality and strengthens the human's need for activities, practices that he/she incorporates to takes care of his healthy lifestyle, because he/she is responsible for himself/herself, for his/her psychosomatic well-being. New Agers often perceive illness as an internal discordance, an imbalance of mismatches that contradicts the wholesome/holistic harmonization of the mind and body; therefore, for them searching for health is not only a matter of physical pleasure, but also a necessity and spiritual growth (Ban, 2008:87). This confirms the fact that the concern for a healthy lifestyle, that is, the concern for one's own health, acts as an ideological concept, since health is an important social value, a good that every individual is trying to maintain with different practices (allopathic, New Age, healthy lifestyle), which brings pleasure and feelings of happiness to them, as Toš and Malnar research (2002:87-95) has found.

Various healing behaviour patterns (related and unrelated to religion) influence the health of an individual:

"As long as a person is healthy, "hahaha", but when suddenly be feels ill, the closest way is to Mary. I am convinced, if nothing else, that it is a spiritual healing or power, so that a person can then accept this disease, to start thinking differently." (Informant No. 60, priest)

or

"I think that this is a possible approach that seems to be scientific, where the frequencies of certain places are measured and compared with the frequencies of individual organs, which is probably one option, but the question is, if this is sufficiently comprehensive, because of ... it is sensible for human health to also enrich human beings in a spiritual sense, in terms of their spiritual development." (Informant No. 2, geomant). 


\section{Conclusion}

The research has shown that the basic division of behaviour patterns in places of power is closely related to the reasons why people come to these places. On this basis, five thematic groups of behaviour in relation to activities that are linked to tourist, religious (traditional Catholic and New Age), healing, personal / individual and consumer behaviour patterns were identified. Special attention was given to the New Age behaviour patterns, since New Agers also create new, diverse patterns of behaviour in the Slovenian modern contemporary secularized society. Among them are patterns of behaviour associated with sitting or standing at marked energy points with the emission of "beneficial" energy, patterns associated with drinking water from Ivan's spring in the place of power, and patterns of behaviour associated with the geomantic healing of Earth and themselves.

Behaviour patterns are intertwined in the places of power, and although they coexist, one pattern of behaviour always prevails in each place; in one explored place, tourist practices predominate, in the other traditional Catholic behaviour patterns, and in the third, quite marginal place, which is almost abandoned as a pilgrimage centre and which has not been particularly attractive to tourists in the past, New Age patterns of behaviour.

The research also confirms the fact that traditional Catholic, pilgrimage and tourist patterns of behaviour have been preserved and partially transformed in the places of power, and New Age patterns of behaviour, which are widespread in two explored areas of power, appeared at the same time. In the place of power where the Catholic Church has its primacy, New Age behaviour patterns have not expanded.

Within five groups of behaviour patterns, the most common behavioural practices are focused on maintaining or gaining health, which is confirmed by the fact that health is becoming a kind of a metaphysical concept and an extremely important value for which individuals are willing to travel to places of power, and that the desire and the need for "doing something for themselves" at different levels indicate an aspiration of a modern Slovenian seeking personal growth.

The important places of power in Northeastern Slovenia thus remain the same as they were centuries ago (according to some New Age statements (Pogačnik, 2010) even millennia). People still come to such places, seeking relaxation, help, health and spiritual transformation. The modern consumer society gives, along with a multitude of material things and data, a void to the individual, which some try to overcome by the spiritual aspects of life. Some individuals try to fill their internal development with some individuals (some claim they succeed in doing so) by coming to these special places and including various rituals, thoughts (many stem from the Eastern spirituality); but it is interesting that they do not name themselves New Agers, and that many also do not want to leave their primary religion, but in their individuality they combine elements of different spiritualties. 


\section{References}

1. Adam, P. and Herzlich, C. (2002). Sociologija bolezni in medicine. Ljubljana: Društvo pljučnih in alergijskih bolnikov Slovenije.

2. Antonov, V. Encyclopedia of Spiritual Knowledge. Available at: http://www. encyclopedia-of-religion.org/places of power.html. (Accessed 27 January 2019)

3. Badone, E. and Roseman, S. R. (2004). Intersecting Journeys: The Anthropology of Pilgrimage and Tourism. Urbana and Chicago: University of Illinois Press.

4. Bahovec, I. (2009). Postmoderna kultura in dubovnost: religioznost med new agem in krščanstvom. Ljubljana: Inštitut za razvojne in strateške analize.

5. Ban, T. (2008). Novodobniška duhovnost: od zgodovinskih izvirov do sodobne podobe. Ljubljana: Fakulteta za družbene vede.

6. Ban, T. (2014). Sveti kraji novodobniške duhovnosti, in: Furlan Štante, N. and Harcet, M. (Eds.). Dubounost žensk na Slovenskem. Koper: Univerza na Primorskem, Znanstveno-raziskovalno središče, Univerzitetna založba Annales.

7. Bourdieu, P. (1997). Out Line of a Theory of Practice. Cambridge; New York; Melbourne: Cambridge University Press.

8. Castaneda, C. (1995). Učenje pri don Juanu. Ljubljana: Gnosis in Quatro.

9. Cazeneuve, J. ([1971] 1986). Sociologija obreda. Ljubljana: ŠKUC: Znanstveni inštitut Filozofske fakultete.

10. Črnič, A. (2012). Na vodnarjevem valu: Nova religijska in dubouna gibanja. Ljubljana: Fakulteta za družbene vede, Založba FDV.

11. Durkheim, E. ([1971] 1976). The Elementary Forms of There Ligious Life. London: George Allenand Unwi.

12. Eade, J. and Sallnow, M. J. (1991). Contesting The Sacred: The Anthropology of Christian Pilgrimage. London; New York: Routledge.

13. Gordillo, G. (2002). The Dialectic of Estrangement: Memory and the Production of Places of Wealth and Poverty in the Argentinean Chaco. Cultural Anthropology, 17 (1): 3-31.

14. Gray, M. (2007). Sacred Earth: Places of Peace and Power. New York: Sterling.

15. Greenfield, S. M. (1990). Turner and anti-Turner in the Image of Christian Pilgrimage in Brazil. Anthropology of consciousnees, 1 (3-4): 1-8.

16. Hanegraaff, W. J. (1996). New Age Religion and Western Culture. Koeln: E. J. Brill.

17. Heelas, P. (2003). The New Age Movement: The Celebration of the Self and the Sacralization of Modernity. Cambridge; Oxford: Blackwell.

18. Huntsinger, L. and Fernandez-Gimenez, M. (2000). Spiritual Pilgrims at Mount Shasta, California. The Geographical Review, 90 (4): 536-558.

19. Ivakhiv, A. (2003). Nature and Self in New Age Pilgrimage. Culture and Religion, 4 (1): 93-118.

20. Kandrič, I. (2015). Razlogi za obiskovanje prostorov moči / Reasons for visiting places of power, in: Filej, B.a et al. (Ed.). Mednarodna znanstvena konferenca Znanost in kultura za zdravo družbo. Zbornik prispevkov z recenzijo, p. 169174.

21. Kravanja, B. (2011). Prostor in njegova zmožnost delovanja ali kaj imajo skupnega Slovenija, Makedonija in Šrilanka, in: Klaus, S. and Kvartič, K. (Eds.). Uporaba prostorov: strokovni zbornik. Ljubljana: Znanstvena založba Filozofske fakultete. 
22. Leach, E. R. and Aycock, A. (1988). Strukturalističke interpretacije biblijskog mita. Zagreb: August Cesarec.

23. Lefebvre, H. (2013). Produkcija prostora. Ljubljana: Studia Humanitatis.

24. Lipovec Čebron, U. (2008). Krožere zdravja in bolezni: tradicionalna in komplementarne medicine $v$ Istri. Ljubljana: Filozofska fakulteta, Oddelek za etnologijo in kulturno antropologijo.

25. Lovelock, J. E. and Margulis, L. (1974). Atmospheric Homeostasis by and for the Biosphere: The Gaia Hypothesis. Tellus, 26 (1-2): 2-10.

26. Marcus, G. E. (1995). Ethnography in/of the World System: The Emergence of Multi-Sided Etnography. Annual Review of Ethnography, 24 (1): 95-117.

27. Morinis, A. (1992). Sacred Journeys - The Territory of the Anthropology of Pilgrimage. The Anthropology of Pilgrimage. London: Greenwood Press.

28. Nash, D. J. (2002). The Archaelogy of Space: Places of Power in the Wari Empire. (A Dissertation of Philosophy). Florida: University of Florida.

29. Olsen, D. H. (2008). Contesting Identity, Space and Sacred Site Management at Temple Square in Salt Lake City, Utah. Waterloo, Ontario: University of Waterloo.

30. Pernecky, T. (2006). Usuglašavanje sa svemirom: fenomenološka studija New Age turista. Časopis Turizam, 54 (2): 143-159.

31. Petrič, F. (2008). Slovenske božje poti. Ljubljana: Družina.

32. Pogačnik, M. (2010). Skrivno življenje Zemlje/Sacred Geography. Mengeš: Bird Publisher.

33. Potrata, B. (2001a). Duhovnost nove dobe. Časopis za kritiko znanosti: Šola v globalnem kapitalizmu; Dubovna veleblagovnica, 29 (202-203): 163-179.

34. Potrata, B. (2001b). Verske ideje, verske prakse: slovenski novodobniki in njihove prakse. Teorija in praksa, 28 (6): 1144-1154.

35. Ramšak, M. (1996). Filigranski pogled na prepletanje religiozne in profane funkcije romanja na primeru Ruškega. Časopis za zgodovino in narodopisje, 67 (1): 94-103.

36. Sax, W. S. (2009). Landscape, Memory, and Ritual. Oxford: University Press.

37. Stojanović, L. (2004). Places of Power. Novi Sad: Ljubiša Stojanović. Available at: https://the-eye.eu/public/concen.org/Kundalini\%20Tantra\%20Yoga\%20 Chakra\%20Meditation\%20\%5Bbook\%20pack\%5D/PDF/Ljubisa\%20Stojanovic\%20 \%20 Places\%20of\%20 Power.pdf. (Accessed 5 March 2019)

38. Stokowski, P. (2008). Symbolic Aspects of Water, in: Stephen F. McCool; Roger N. Clark and George H. Stankey (Eds.). Water and People: Challenges at the Interface of Symbolic and Utilitarian Values. Washington: U.S. Department of Agriculture.

39. Šmitek, Z. (2017). Mitološko izročilo Slovencev: svetinje preteklosti. Ljubljana: Beletrina.

40. Toš, N. and Malnar, B. (2002). Družbeni vidiki zdravja. Sociološka raziskovanja odnosa do zdravja in zdravstva. Ljubljana: Fakulteta za družbene vede, IDV CJMMK.

41. Turner, V. (1978). Image and Pilgrimage in Christian Culture: Anthropological Perspectives. New York, Columbia University Press.

42. Ule, M. (2003). Spregledana razmerja: o družbenih vidikih sodobne medicine. Maribor: Aristej.

43. Book of impression on Ptujska Gora (3. May 2009 - 8. August 2009). Ptujska Gora: Parish office Ptujska Gora. 
Izvorni znanstveni rad

Irena Kandrič

Osnovna škola Ormož, Slovenija

e-mail:irena.kandric@guest.arnes.si

Obrasci ponašanja na mjestima moći u sjeveroistočnoj Sloveniji

\section{Sažetak}

Ovaj članak razmatra mjesta moći kao društveno-kulturno proizvedene lokalitete i povezuje ih s religijom, turizmom i zdravljem. Obrađuju se i klasificiraju obrasci ponašanja koje su oblikovali razni posjetitelji triju nekad pretežno hodočasničkih mjesta u sjeveroistočnoj Sloveniji (Razkrižje, Jeruzalem, Ptujska Gora). Ispitivanje posjeta ovim mjestima moći u kombinaciji s promatranjem, kvalitativnim intervjuima i analizama zapisa u knjigu dojmova pokazalo je da se posjetitelji mogu podijeliti u pet grupa, koje se djelomično isprepliću na temelju aktivnosti povezanih s turističkim, vjerskim (tradicionalnim katoličkim i new age) ponašanjem, s komplementarnom i alternativnom medicinom, te s osobnim/individualnim obrascima ponašanja. Rezultati potvrđuju da se u slovenskom sekularnom društvu još uvijek izvode stari (tradicionalno katolički) rituali te da se često provode rituali new age-a.

Ključne riječi: antropologija, mjesto, mjesta moći, new age, zdravlje, ritual. 